Вдовіна Олена Олександрівна кандидат наук з соціальних комунікацій, доцент кафедри українознавства, культури та документознавства, Національний університет «Полтавська політехніка імені Юрія Кондратюка», Першотравневий проспект 24, м. Полтава, 36011, тел.: (093) 455-09-89, e-mail: svitljahok@gmail.com, https://orcid.org/0000-0003-3770-125X

\title{
ОСОБЛИВОСТІ ВИКЛАДАННЯ НАВЧАЛЬНОЇ ДИСЦИПЛІНИ «БІБЛІОТЕКОЗНАВСТВО ТА КНИГОЗНАВСТВО» ДЛЯ ФАХІВЦІВ 3 ІНФОРМАЦІЙНОЇ, БІБЛІОТЕЧНОЇ ТА АРХІВНОЇ СПРАВИ
}

Анотація. Національна доктрина розвитку освіти України у XXI столітті закріпила положення про те, що підготовка конкурентоспроможних фахівців $\epsilon$ центральним завданням модернізації освіти, провідним принципом державної освітньої політики. Важливим аспектом професійної діяльності кожного фахівця $є$ постійне поповнення й оновлення знань. Обсяг інформації, необхідний для плідної роботи за фахом, невпинно зростає. Вивчений матеріал швидко втрачає актуальність і потребує оновлення. Тому навчання, орієнтоване лише на запам'ятовування, не може задовольнити сучасні вимоги до фахівця. Першочерговою $є$ проблема формування таких якостей людини, які дають можливість самостійно засвоювати нову інформацію, розвивати вміння та навички, необхідні для виконання діяльності на високому професійному рівні. Тому вітчизняна модель професійної підготовки, яка була спрямована в основному на передачу молодому спеціалістові необхідних знань, умінь і навичок, втрачає свою значущість [1]. Сьогодні при викладанні кожної навчальної дисципліни, у тому числі й «Бібліотекознавство та книгознавство», у закладах вищої освіти України широко використовуються як традиційні, так і нетрадиційні методи навчання. Жодним чином не відмовляючись від традиційних методів навчання у вищій школі, все частіше використовують нетрадиційні методи, оскільки вони більше активізують студентів, розвивають їхні індивідуальні здібності, ерудицію й уяву, сприяють діалогові між викладачем і студентами, виявленню часом суперечливих проблем. У статті зроблена спроба проаналізувати особливості викладання дисципліни «Бібліотекознавство та книгознавство» для студентів спеціальності 029 «Інформаційна, бібліотечна та архівна справа» на прикладі Національного університету «Полтавська політехніка імені Юрія Кондратюка». Розкрито специфіку проведення практичних занять, у 
тому числі за допомогою платформи дистанційної освіти Moodle, зосереджена увага на доцільності візуалізації матеріалу за допомогою мультимедійних технологій, проаналізовано важливість та значущість опанування студентами програмних продуктів для автоматизації бібліотек, описано способи ефективного проведення практичних занять для кращого засвоєння навчального матеріалу.

Ключові слова: навчальна дисципліна, бібліотекознавство, книгознавство, інформаційна, бібліотечна, архівна справа, особливості викладання навчальної дисципліни.

Vdovina Olena Oleksandrivna $\mathrm{PhD}$ of Social Communication, Associate professor department of ukrainian studies, culture and documentation, National University «Yuri Kondratyuk Poltava Polytechnic», Pershotravnevyi Av. 24, Poltava, 36011, tel.: (093) 455-09-89, e-mail: svitljahok@gmail.com, https://orcid.org/00000003-3770-125X

\title{
FEATURES OF TEACHING THE EDUCATIONAL DISCIPLINE "LIBRARY SCIENCE AND BOOK STUDIES" FOR SPECIALISTS IN INFORMATION, LIBRARY AND ARCHIVAL AFFAIRS
}

\begin{abstract}
The National Doctrine for the Development of Education of Ukraine in the 21 st Century established the provision that the training of competitive specialists is the central task of modernizing education, the leading principle of State educational policy. An important aspect of the professional activity of each specialist is the constant replenishment and renewal of knowledge. The amount of information necessary for fruitful work in the specialty is constantly growing. The material studied quickly loses relevance and requires updating. Therefore, memorization-only training cannot meet the modern requirements of a specialist. The primary problem is the formation of human qualities that allow you to independently learn new information, develop the skills and skills necessary to perform activities at a high professional level. Therefore, the domestic model of vocational training, which was aimed mainly at transferring the necessary knowledge, skills and skills to a young specialist, is losing its significance. Today, in the teaching of each academic discipline, including "Library Science and Book Science," both traditional and non-traditional teaching methods are widely used in higher education institutions in Ukraine. In no way abandoning traditional methods of higher education, they are increasingly using non-traditional methods, as they more activate students, develop their individual abilities, erudition and imagination, promote dialogue between the teacher and students, and identify sometimes contradictory problems. The article attempts to analyze the features of teaching the discipline "Library Science and Book Studies" for students of specialty 029 "Information, Library and
\end{abstract}


Archival Business" using the example of the National University "Yuri Kondratyuk Poltava Polytechnic». The specifics of conducting practical classes are disclosed, including through the Moodle distance education platform, attention is focused on the expediency of visualizing the material using multimedia technologies, the importance and significance of students mastering software products for automation of libraries are analyzed, methods of effective conducting practical classes for better assimilation of educational material are described.

Keywords: educational discipline, library science, book science, information, library, archival business, peculiarities of teaching educational discipline.

Постановка проблеми. Аналіз різноманітних аспектів підготовки фахівців 3 інформаційної, архівної та бібліотечної справи ( далі - ІБАС) неодноразово ставав об'єктом досліджень науковців, проте проблема цілісного дослідження особливостей викладання окремих дисциплін, що є обов'язковими до вивчення майбутніми фахівцями спеціальності ІБАС, «Бібліотекознавство та книгознавство» зокрема, ще не було предметом спеціального дослідження.

Аналіз останніх досліджень i публікацій. Свої праці дослідженню теоретичних аспектів професійної підготовки фахівців інформаційної, бібліотечної та архівної справи присвятили О. Карпенко, Л. Кисельова, Н. Кушнаренко, С. Кулешов, Ю. Палеха, I. Прокопенко, I. Петрова, M. Слободяник та ін. Досліджувалися окремі аспекти формування науковометодичного забезпечення навчального процесу (Я. Болюбаш, О. Дубасенюк, В. Козаков, В. Харабет, Г. Шемелюк, Г. Гребенюк та ін.) [2].

Мета статті - дослідження специфіки та особливостей викладання дисципліни «Бібліотекознавство та книгознавство» фахівцям спеціальності ІБАС.

Виклад основного матеріалу. Суспільна потреба у фахівцях з інформаційної діяльності є свідченням поширення в університетах України підготовки молодих кадрів за спеціальністю «Інформаційна, бібліотечна, архівна справа» (далі - ІБАС) в «Переліку галузей знань і спеціальностей, за якими здійснюється підготовка здобувачів вищої освіти» [3]. Здійснивши інтернет-моніторинг офіційних вебсайтів закладів вищої освіти ( далі - 3ВО) в Україні можемо зробити висновок, що нині близько 50 освітніх установ готують фахівців спеціальності ІБАС.

Щорічно високий конкурс абітурієнтів на підготовку бакалаврів спостерігається у Національному університеті «Полтавська політехніка імені Юрія Кондратюка». Цікавою й багатою $\epsilon$ історія підготовки фахівців гуманітарного профілю університету, яка своїм корінням сягає років здобуття Україною незалежності. Необхідність реалізації Закону УРСР «Про мови...» в навчально-виховному й науково-дослідницькому процесі закладу вищої освіти (далі - 3ВО) зумовила рішення вченої ради та наказ ректора № 61 від 24 січня 
1991 року про створення однієї з перших серед вищих технічних навчальних закладів України кафедри українознавства та гуманітарної підготовки.

У 2012-2013 навчальному році кафедра стала випусковою за напрямом підготовки «Документознавство та інформаційна діяльність» (3 2015 року відповідно до Постанови Кабінету міністрів України № 266 «Про затвердження переліку галузей знань і спеціальностей, за якими здійснюється підготовка здобувачів вищої освіти», - за спеціальністю 029 «Інформаційна, бібліотечна та архівна справа») освітньо-кваліфікаційного рівня бакалавр і була перейменована у кафедру українознавства, культури та документознавства ( далі - УКД). У 2017 році кафедра успішно пройшла акредитацію магістерської, а у 2021 бакалаврської освітньої програми «Документознавство та інформаційна діяльність» [4].

Заслуговує на увагу й той факт, що кафедра УКД у царині науководослідницької роботи працює над комплексною науковою темою «Духовна культура України, Полтавщини (XIX-XX ст.)», а також над темою, що відповідає iї профілю як випускової, - «Документно-інформаційні комунікації в умовах сучасних глобалізаційних викликів». Щорічно кафедрою проводяться наукові й науково-практичні конференції, круглі столи відповідної тематики - від регіональних до Всеукраїнських. Зокрема, з 2015 року кафедрою започатковано проведення щорічної Всеукраїнської науково-практичної Internet-конференції «Документно-інформаційні комунікації в умовах глобалізації: стан, проблеми i перспективи». До участі у наукових заходах активно долучаються й студенти спеціальності ІБАС, які під керівництвом науково-педагогічних працівників кафедри готують доповіді та презентації своїх матеріалів. Високий рівень практичної підготовки фахівців забезпечується розвиненою інфраструктурою навчального закладу, досвідченими викладачами, наявністю спеціалізованих кабінетів, комп'ютерних лабораторій, наявністю відповідного програмного забезпечення [4].

«Бібліотекознавство та книгознавство» - важлива складова підготовки бакалаврів в системі вищої освіти та обов'язковий компонент освітньопрофесійної програми, що входить до циклу дисциплін професійної підготовки здобувчів освіти спеціальності 029 «Інформаційна, бібліотечна та архівна справа». Всебічне дослідження бібліотеки та книги, як соціальних феноменів та невід’ємної складової національної культури дозволяє простежити особливості національно-культурного становлення України, розвитку сучасного українського суспільства з урахуванням ідеологічних, соціально-політичних, культурних i технологічних змін, що сталися в країні [5]. Саме тому, метою вивчення дисципліни є надання студентові суми знань, яка б дозволила йому простежити шлях розвитку бібліотеки та книги з часу виникнення, визначити їх функції на 
кожному етапі розвитку, місце в системі сучасних комунікацій та засобів масової інформації, зв’язок $з$ іншими гуманітарними науками. Дисципліна передбачає широку загальнотеоретичну підготовку студентів.

Для ретельного аналізу особливостей викладання, вважаємо за доцільне проаналізувати робочу програму навчальної дисципліни. Загальна кількість годин, що відводиться на вивчення - 180 ( 6 кредитів ЕКТС), з яких:

- $\quad$ лекції - 30 год;

- $\quad$ практичні - 32 год;

- $\quad$ самостійна робота студентів - 118 год.

Усі форми навчального процесу є взаємозалежними, взаємозв'язаними, логічно послідовними [6]. Таким чином, співвідношення кількості годин аудиторних занять до самостійної роботи становить - 62/118.

Лекційна форма викладання має значні переваги, які полягають у безпосередньому впливі лектора на велику кількість студентів одночасно, ефективності засвоєння матеріалу, можливості формування світогляду та переконання тощо.

Для цього необхідно дотримуватися універсальних вимог до проведення лекційних занять, що полягають у:

1) науковості, систематичності викладення матеріалу;

2) логічності цілей і задач вивчення матеріалу, організації змісту;

3) доступності, ясності, об’єктивності і послідовності у викладу матеріалу;

4) активізації пізнавальної діяльності студентів шляхом проблемності викладення навчального матеріалу, апеляції до безпосередніх інтересів аудиторії тощо;

5) уніфікації у використанні термінології і позначень [6].

Практичні заняття $\epsilon$ необхідними складовими навчального процесу, що спонукають студентів самостійно засвоювати знання [6]. Самостійна робота студентів передбачає відпрацювання лекцій, підготовку й активну участь студентів у практичних заняттях, після вивчення та конспектування літератури й джерел, підготовку іспиту, підготовку контрольних, тощо. Вивчається здобувачами в Національному університеті «Полтавська політехніка імені Юрія Кондратюка» на 3 курсі впродовж 1 семестру. Засобом діагностики результатів навчання є екзамен.

Програма охоплює систему компетентностей та програмні результати навчання, які чітко виявляють орієнтацію підготовки майбутніх фахівців як професіоналів з високим рівнем володіння інформаційними технологіями.

Програмні результати навчання виявляються у сформованих у студентів здатностях щодо:

-абстрактного мислення, аналізу та синтезу; 
-використання інформаційних і комунікативних технологій;

-пошуку, опрацювання та аналізу інформації з різних джерел;

-здатності працювати в команді та спілкуватися 3 представниками інших професійних груп різного рівня (з експертами 3 інших галузей знань);

-реалізації своїх прав та обов’язків як члена суспільства, усвідомлення цінності громадянського (вільного демократичного) суспільства та необхідність його сталого розвитку, верховенства права, прав і свободи людини і громадянина в Україні [7];

-збереження та примноження моральних, культурних та наукових цінностей i досягнень суспільства на основі розуміння історії та закономірностей розвитку предметної області, їі місця в загальній системі знань про природу і суспільство та у розвитку суспільства, техніки і технологій, використовувати різні види та форми рухової активності для активного відпочинку та ведення здорового способу життя;

- забезпечення відбору, аналізу, оцінки, систематизації, моніторингу, організації, збереження, розповсюдження та надання в користування інформації та знань у будь-яких форматах;

-впровадження інноваційних технологій виробництва інформаційних продуктів i послуг, підвищення якості інформаційного обслуговування користувачів інформаційних, бібліотечних та архівних установ;

-проєктуванні та створенні документно-інформаційних ресурсів, продуктів та послуг;

- постійного підвищення рівня інформаційної культури;

-застосуванні прикладного програмного забезпечення, зокрема, текстових редакторів, СЕД, електронних таблиць, СУБД [7].

Програмою передбачено, що у результаті вивчення навчальної дисципліни «Бібліотекознавство та кнгознавство» студент повинен знати:

-загальні тенденції, історію і сучасний стан розвитку вітчизняного та зарубіжного бібліотекознавства та книгознавства;

-понятійно-категоріальний апарат бібліотекознавства та книгознавства; основні типи і види бібліотек, їх соціальні функції;

-законодавче забезпечення книговидавничої справи;

-нормативно-правове регулювання бібліотечної діяльності;

-основні категорії та принципи організації бібліотечної справи;

уміти:

-застосовувати у професійній діяльності методологію вивчення та задоволення культурних та інформаційних потреб користувачів;

-узагальнювати, аналізувати і синтезувати інформацію в діяльності, пов’язаній із їі пошуком, накопиченням, зберіганням та використанням; 
-застосовувати в практичній діяльності законодавчі та галузеві нормативні документи;

-забезпечувати ефективність функціонування документно-комунікаційних систем;

-кваліфіковано використовувати типове комп'ютерне та офісне обладнання; здійснювати пошук інформації в різних джерелах для розв’язання професійних завдань;

-застосовувати сучасні методики і технології автоматизованого опрацювання інформації, формування та використання електронних інформаційних ресурсів та сервісів життєдіяльності [7].

Програма навчальної дисципліни складається 3 1 змістового модуля «Бібліотекознавство та книгознавство як складова підготовки фахівця 3 документознавства та інформаційної діяльності», у рамках якого виділені 10 тем лекційних занять:

1. Бібліотекознавство як наука. Бібліотека в системі соціальних комунікацій;

2. Історія становлення та основні етапи розвитку бібліотекознавства;

3. Організація і функціонування бібліотечної справи в Україні на сучасному етапі;

4. Система управління бібліотечною справою.

5. Довідково-бібліографічний апарат бібліотеки;

6. Книгознавство як наука. Виникнення та еволюція поняття «книга»;

7. Конструкція і структура книги;

8. Апарат книги;

9. Типологія книги як книгознавча проблема. Типи та жанри літератури; Бібліографічне обслуговування і його види;

10. Сучасні засоби автоматизації бібліотечного та інформаційного обслуговування та відповідно 10 тем практичних занять. Варто зауважити, що враховуючи інтегрований характер дисципліни (поєднання бібліотекознавчої та книгознавчої складових) на кожну з них відводиться рівна кількість занять.

Особливістю викладання дисципліни $\epsilon$ й те, що частина лекційних та практичних занять проводиться у науково-технічній бібліотеці ( далі - НТБ) Національного університету «Полтавська політехніка імені Юрія Кондратюка». Студенти мають можливість ознайомитися 3 ліцензійним програмним забезпеченням, встановленим у бібліотеці та набути навички роботи з ним. У НТБ встановлена автоматизована бібліотечна інформаційна система ( далі - АБІС) «Університетська бібліотека «UniLib» (розробник Харківський інститут внутрішніх справ). Програма була придбана університетом для НТБ у 2003 р. на умовах подальшого доопрацювання і налаштування.

Регулярно здійснюється оновлення програми до останньої версії, ії підтримка 
та налаштування. Здобувачі вищої освіти під керівництвом викладача та провідного спеціаліста бібліотеки ознайомлюються 3 основними, автоматизованими завдяки програмі, бібліотечними процесами, зокрема:

- комплектування фонду (від реєстрації нових надходжень до роздрукування інвентарних книг);

- наукове оброблення документів;

- інформаційно-бібліографічне обслуговування (аналітичний розпис нових надходжень, виконання довідок з використанням електронних ресурсів);

- обслуговування читачів (видача і прийом літератури за допомогою штрихкодової технології для ідентифікації як читачів, так і книг).

На практичних заняттях студенти опановують головні модулі програми АБІС та вивчають їх функціональні можливості, зокрема:

1. Модуль «Комплектатор»

2. Модуль «Книги обліку»

3. Модуль «Бібліограф»

4. Модуль «Обслуговування читачів»

5. Модуль «Реєстрація»

6. Модуль «Статистика»

7. Модуль «Довідковий відділ»

8. Модуль «Налаштування»

Окрім опанування програмного продукту АБІС «Університетська бібліотека «UniLib» студенти також навчаються роботі 3 інституційним репозитарієм Університету.

Інституційний репозитарій Національного університету «Полтавська політехніка імені Юрія Кондратюка - eNUPPIR Electronic National University «Yuri Kondratyuk Poltava Politechnic» Institutional Repository (http://reposit.nupp.edu.ua/) є платформою для наукових публікацій науковопедагогічних працівників і здобувачів вищої освіти шляхом їх розміщення у глобальній мережі. Працівниками науково-технічної бібліотеки здійснюється адміністрування (на базі пакету вільного/відкритого П3 «DSpace»), редагування, наповнення та статистичний облік. На кінець 2020 року Інституційний репозитарій налічує 8350 документів i $\epsilon$ базою даних для інформаційного забезпечення освітнього i наукового процесів університету, електронного та дистанційного навчання. Інституційний репозитарій університету $є$ унікальним фондом видань наукової та частково навчальної тематики за профілем університету. Репозитарій налічує 54 фонди та зібрання. Серед країн, які найбільше переглядають Інституційний репозитарій університету: Україна, Китай, США, Німеччина, Великобританія. НТБ до репозитарію занесено 2037 наукових праць. За рік зафіксовано 675570 звернень до репозитарію. Провідні 
фахівці надають консультативну допомогу науково-педагогічним працівникам щодо розміщення наукових праць а електронному архіві, а також здійснюють редагування бібліографічних записів у цих працях. Під керівництвом співробітників НТБ студенти практикують наповнення репозитарію новими науковими працями та систематизацію занесених у нього матеріалів.

Важливу роль в опануванні дисципліни та набутті знань відіграють також нестандартні форми проведення практичних занять. Зі студентами спеціальності ІБАС Національного університету «Полтавська політехніка імені Юрія Кондратюка» практичні заняття часто проводяться у формі хакатонів, диспутів, дебатів, круглих столів. Використовуються методи «мозкового штурму», «дерева рішень» та ділової гри.

Заслуговує на увагу й процес вивчення дисципліни студентами в умовах карантинних обмежень. Пандемія коронавірусу змусила усі 3 ВО перейти на дистанційне навчання. Опанування навчального матеріалу реалізується двома шляхами:

1. Проведення лекційних та практичних занять за допомогою систем відеоконференцзв'язку Zoom;

2. Проведення практичних занять та самостійної роботи студентів із використанням платформи дистанційної освіти Moodle, доступ до якої відбувається за допомогою переходу через офіційний сайт університету шляхом введення власного логіну та паролю.

На початку навчального року студенти приєднуються до оболонок дисциплін, що вивчатимуть та автоматично отримують доступ до усіх матеріалів розміщених в оболонці дисципліни. Курс «Бібліотекознавство та книгознавство» на платформі Moodle мітить:

1. Робочу навчальну програму дисципліни,

2. Сілабус,

3. Глосарій дисципліни,

4. Текстові документи до усіх лекційних занять,

5. Презентації у форматі PowerPoint до усіх лекцій,

6. Методичні рекомендації до вивчення дисципліни,

7. Плани семінарських занять,

8. Теми для підготовки рефератів та презентацій,

9. Перелік тем для самостійного вивчення студентами,

10. Перелік рекомендованої літератури до курсу,

11. Словники з бібліотечної справи та УДК,

12. Тестові завдання для міжсесійного контролю знань,

13. Екзаменаційний тест ( на випадок дистанційного проведення сесії),

14. Тестові завдання до кожної теми, 
15. Відеоуроки та допоміжні відеоматеріали.

Усі вище перераховані матеріали доступні (для перегляду та завантаження) зареєстрованим студентам 24/7. Здобувачі з задоволенням переглядають відео, що підвантажені на платформу та віддають перевагу електронним конспектам лекцій над паперовими.

Проведення тестувань на платформі дистанційної освіти дає змогу викладачеві формувати пакети тестових завдань за конкретною темою, модулем чи курсом; завантажувати питання нові чи з бази питань; формулювати питання закритого чи відкритого типу, есе чи питання із встановленням відповідності або ж питання типу правильно/неправильно. Викладач на власний розсуд та з огляду на кількість пройденого матеріалу може регулювати тривалість часу на виконання завдань, кількість спроб на проходження тощо. Вигляд оболонки навчальної дисципліни на дистанційній платформі зображено на рис.1. та рис. 2.
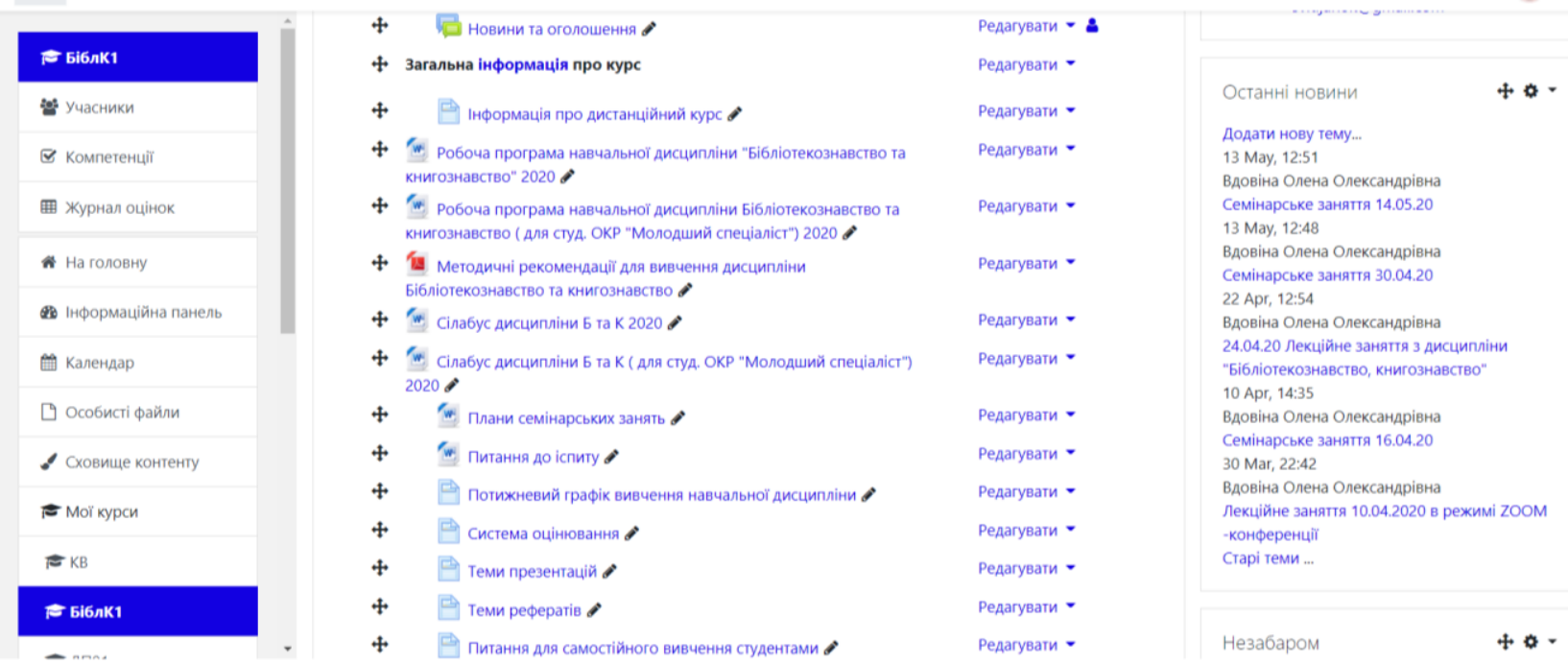

Рис.1 Оболонка навчальної дисципліни «Бібліотекознавство, книгознавство» на платформі дистанційної освіти Moodle
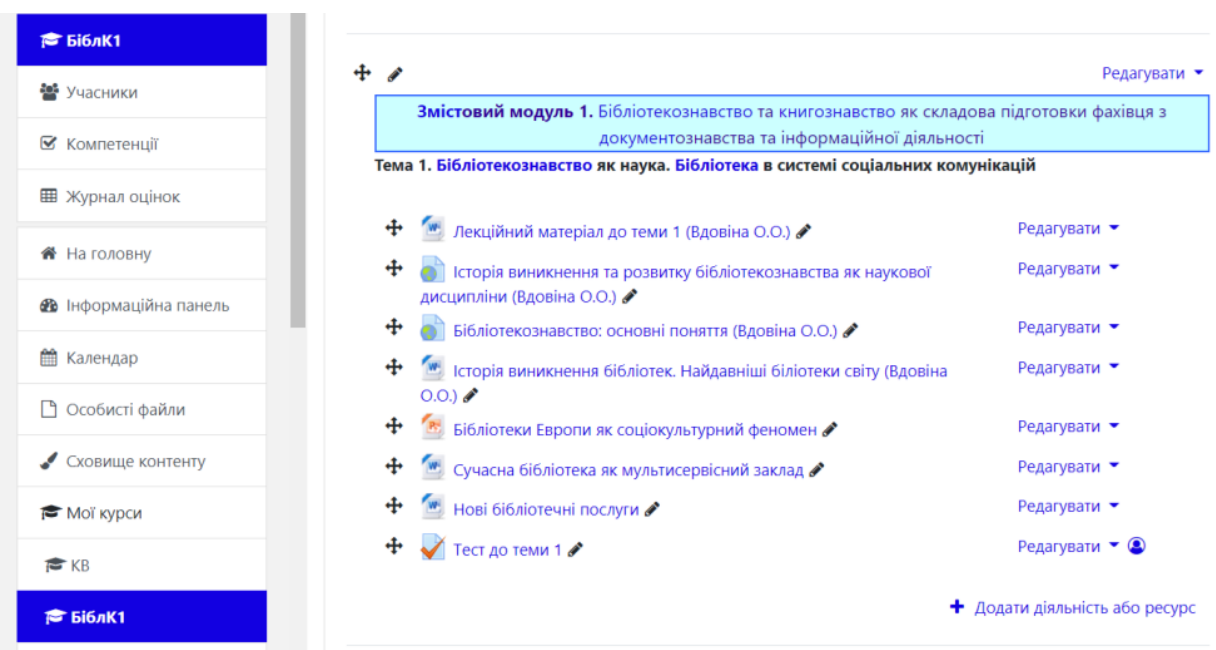

Pис.2 Подача навчального матеріалу в оболонці дисиипліни «Бібліотекознавство, книгознавство» на платформі дистанційної освіти Moodle 
Висновок. Підсумовуючи вище викладене можна зробити висновок, що особливості викладання дисципліни «Бібліотекознавство та книгознавство» для студентів спеціальності ІБАС полягають у: використанні мультимедійних засобів для візуалізації матеріалу, набутті практичних навичок роботи 3 програмними продуктами та інституційним репозитарієм, збільшенні кількості годин практичних занять у порівнянні з лекційними, застосуванні нестандартних форм проведення практичних занять, опрацювання матеріалу за допомогою платформи дистанції освіти Moodle. Вважаємо, що такий підхід до викладання дисципліни дає можливість майбутнім випускникам краще засвоїти матеріал, набути необхідних знань та компетенцій та, зрештою, бути конкурентоспроможними та затребуваними на ринку праці.

\section{Лimepamypa:}

1. Брюховецька О. Застосування нетрадиційних семінарських занять при підготовці студентів зі спеціальності «психологія». URL: https://cutt.ly/yv0E3xz (дата звернення 15.04.2021)

2. Кухтяк О. Концептуальні засади науково-методичного забезпечення підготовки фахівців інформаційної, бібліотечної та архівної справи. URL: https://journals.indexcopernicus.com/api/file/viewByFileId/911150.pdf (дата звернення 15.04.2021)

3. Пелещишин А., Комова М., Вовк Н. Дидактичний досвід підготовки фахівців 3 інформаційної діяльності. URL: https://cutt.ly/6v1RwoO (дата звернення 15.04.2021)

4. Офіційний сайт Національного університету «Полтавська політехніка імені Юрія Кондратюка». URL: https://nupp.edu.ua/page/naukovo-doslidna-diyalnist-kafedri-ukrainoznavstvakulturi-ta-dokumentoznavstva.html (дата звернення 16.04.2021)

5. Робоча навчальна програма 3 дисципліни «Книгознавство». URL: https://ij.kubg.edu.ua/images/phocagallery/Podii2020/iba_docx/Knygoznavstvo.pdf (дата звернення 16.04.2021)

6. Карпенко О. Методика викладання документознавства як фундаментальної навчальної дисципліни в підготовці фахівців-документознавців. URL: file:///D:/Downloads/gumc_2007_2_ 18\%20(1).pdf ( дата звернення 20.04.2021)

7. Робоча програма навчальної дисципліни «Бібліотекознавство та книгознавство». URL: https://cutt.ly/Uv0YIKN ( дата звернення 20.04.2021)

\section{References:}

1. Briukhovets'ka O. Zastosuvannia netradytsijnykh seminars'kykh zaniat' pry pidhotovtsi studentiv zi spetsial'nosti «psykholohiia». Retrieved from https://cutt.ly/yv0E3xz [in Ukrainian].

2. Kukhtiak O. Kontseptual'ni zasady naukovo-metodychnoho zabezpechennia pidhotovky fakhivtsiv informatsijnoi, bibliotechnoi ta arkhivnoi spravy. Retrieved from https://journals.indexcopernicus.com/api/file/viewByFileId/911150.pdf [in Ukrainian].

3. Peleschyshyn A., Komova M., Vovk N. Dydaktychnyj dosvid pidhotovky fakhivtsiv z informatsijnoi diial'nosti. Retrieved from https://cutt.ly/6v1RwoO [in Ukrainian].

4. Ofitsijnyj sajt Natsional'noho universytetu «Poltavs'ka politekhnika imeni Yuriia Kondratiuka». Retrieved from https://nupp.edu.ua/page/naukovo-doslidna-diyalnist-kafedriukrainoznavstva-kulturi-ta-dokumentoznavstva.html [in Ukrainian]. 
5. Robocha navchal'na prohrama $\mathrm{z}$ dystsypliny «Knyhoznavstvo». Retrieved from: https:/iij.kubg.edu.ua/images/phocagallery/Podii2020/iba_docx/Knygoznavstvo.pdf [in Ukrainian].

6. Karpenko O. Metodyka vykladannia dokumentoznavstva iak fundamental'noi navchal'noi dystsypliny $\mathrm{v}$ pidhotovtsi fakhivtsiv-dokumentoznavtsiv. Retrieved from file://D:/Downloads/ gumc_2007_2_18\%20(1).pdf [in Ukrainian].

7. Robocha prohrama navchal'noi dystsypliny «Bibliotekoznavstvo ta knyhoznavstvo». Retrieved from https://cutt.ly/Uv0YIKN [in Ukrainian]. 